\title{
地方改良運動と模範村・稲取村 \\ Rural promotion by the Ministry of Home Affairs and an advanced village (Inatori) \\ during modem Japanese capitalism (early to mid 1900s)
}

\author{
田口有希实 * 岡部守 $* *$ \\ Yukio Taguchi* Mamoru Okabe** \\ (*日本学術振興会特別研究員) (**東京農業大学) \\ (*JSPS.Research Fellow) (**Tokyo University of Agriculuure)
}

\section{I 本稿の目的}

現在，わが国では地方分権化が推進され，地方 の自立的運営が求められている。しかし，地域社 会および経済の自立には，未だ多くの問題があり， また，地域の掁興および農村計画において大きな 役割を担っている行政市町村の計画方針も万全で あるとは言い難い。市町村の自立的発展は地方分 権化の進展には不可分な要素である。本研究は， 市町村で行われる曟村振興および地域計画の歷史 的展開として地方改良運動を取り上げる。その理 由は, 近代日本の地方振興運動における町村是運 動，地方改良運動，農山漁村経済更生運動という 流れ" 開された地方改良連動が，行政市町村の自主的， 自立的振興を促した運動であったことであり，見 代の市町村を中心とする振興の一助となると考え たことと，また，各市町村における歴史的展開， 当時の辳村計画を明らかにすることは，現代にお ける農村計画を考える上でも重要なことである。

本研究の事例は, 内務省を中心として展開され た地方改良運動の模筑的事跡として全国に喧伝さ れた静岡県賀茂郡稲取村である。この稲取村は 「明治の三大模籁村 ${ }^{(2)}$ 」として表彰され，地方 改良運動が展開された明治後期に脚光を浴びた。 そこで本研究の目的は，稻取村の農村計画・町村 自治を明らかにし，同時代になせ稲取村が注目さ れたのかその要因を視野に入れ検討する。そして， 稲取村の振興策が, 今日の地域振興に活かせる点, 学ぶべき点を考えたい思う。

\section{II 地方改良運動}

地方改良運動は，日本资本主義の産業资本確立， それに続く独占资本形成過程である日露戦争後に 本格的な展開をむかえた。同時代は，资本主義の 確立に伴う社会的諸矛盾が影在化し，大きな社会 問題となった。その問題は，戦時体制の財政膨張 政策による町村財政の困難，農業恐憆下における 農村への商品経済の浸透，農民層分解による共同 体的秩序の動摇であり，また，明治 21 年及び明 治 23 年に成立した地方自治制度は, このような 日露戦争後の状況により, 明治後期には危機的状 況に陷った。これらの問題を解決する事が，明治 政府によって急務であり，帝国主義化する国家体 制を支える町村の政治経済体制の基盤強化，町村 自治体制の確立を目指し，国家（政治）が主導的 な役割を担うため, 内務省を中心として地方改良 事業を展開した。宮地正人氏によれば「地方改良 運動の中心課題は，帝国主義段階の日本国家の諸 要請を受け止め, 町村民の中に浸透させてゆくこ とのできる行政町村の形成にこそあった」，「国家 の諸要請を町村内部に「主体的」に微底させるこ とのできる町村吏員の育成，それを在野で支える 有志集団（中小地主・自作上層）を創り出すこと せ31」であると述べている。

これらの政策課題のため地方改良運動では，行 政市町村による地方自治振興政策を進めた。内務 省は, 中央集権的統治機構の基盤育成，財政基盤 の確立、模筑村の形成，町村自治を担う模範町村 民の育成をめさし，近代地方自治制の制度的補強 
を図り，また地方改良講習会"4!などを開催し， 主体的な各市町村の振興を説き，「町村是」の推 奖，報徳思想の普及を行った。報徳思想《5) は， 地方改良運動の中心的なイデオロギーであるが， その導入に際しては，同運動を中央で推進した内 務官傹を中心に，二宮尊徳及び報徳思想の再評価

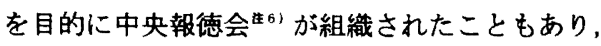
また，会員の多くが府県知事，市町村長，地方吏 員であった事もその要因である。これらの事から 報徳思想は, 地方改良運動のイデオロギー的役割 を担い，各市町村レウェルにまで波及した。

\section{III 模範村・稲取村}

稲取村の経济状態を立て直し，農村振興，町村 自治の模算として，全国に喧伝されるまでになっ た要因の一つには, 明治 22 年の町村制赛地に伴 って初代稲取村村長に選ばれた老農・田村又吉 ${ }^{*}$ ”の貢献がある。同氏は，町村制以前から稲取村 への貢献，農村振興を志し活動を行っていた。村 長を退いてからも一農民として農村振興, 町村自 治の活動を行っている。同氏は, 村長時代以後も 一貫して, 多角的な農業経営を志向していた。そ の農政は「軍事農業」と仮称され，農家経済を軍 隊組織に例えて説いた。つまり田妞による米麦の 収入は「現役兵」，養亘業による収入は「予備 兵」，柑橎による収入は「後備兵」，その他の副業 による収入は「補充兵」として，浸透する商品経 済に備え多角的に経営し生産性を高め，農家経済 の向上を目指した。

稲取村および田村又吉の業績(は)について本稿 では，稲取村の状況，村基本財産の造成に関連し た天草の改良法, 植樹, 勧業および納税制度につ いて，その方法およで過程を論述していく。

\section{1 稲取村の沿革および状況}

静岡県賀茂郡稲取村は，明治元年，廃潘置県に より韮山県, 明治 4 年足柄県, 明治 9 年静岡県の 管轄となり，現在は東伊豆町となっている。面糟 は 1 万 2,530 $\mathrm{km}^{2}$ を有し, 次の三つの地区からな り, 入谷地区は農業を営み, 水下地区は半農半漁, 浜地区が漁業と商業を営んでいた。農業は山間地
域である事により耕作面樌が限られており，耕地 面積は㚼が圧倒的面樌を占め, 自作地での耕作が 基本であった。耕地面積が少ない上に土地生産性 が低く, 明治 11 年 10 月の米の反収量調查では, 反あたり 7 斗 4 升で, 全国平均の 1 石 3 斗 6 升の 約 $54 \%$ \%ありりおく及ばないものであった。人 口は, 明治 34 年の調査 ${ }^{\text {9) }}$ では戸数 814 戸，人口 4,843 人であり，農家戸数 145 戸，専業農業者 455 人は入谷地区であり，漁家戸数は 502 戸，商 業（漁商）戸数は雑業を含め 167 户である。漁家 の女性は，農家の日雇い，耕地を持つものは兼業 で農業を行い，または天草採取などを行っている。 鈴木東藏 ${ }^{(10)}$ によれば，稲取村は幕末期から明 治前半にかけ三回の不可抗的な打慗を受けたとあ る。一回目は, 安政年間に他国の外船が伊豆沖に きてから幕府，諸侯が押し寄せ，村民は夫役の結 果, 職業の放萧を余儀なくされ, また, 明治 6 年, 小学校開設に祭する経費の負担が村民に重くのし かかった。二回目は，天城山の入会権丧失で，天 城山の森林资源による生計も, 明治 12 年に天城 山が宮内省の御料地となり入山を禁止された。三 回目は, 明治 17 年頃, 蒸気船の発達により, 同 地域の五百石積，千石積船のような小型船は海運 業の寸へててが失われた。なかでも天城山の入会権 喊失は農業者にとって大きな打俥であり, 雑木, 下草刚，採草など農家の燃料，肥料，牛馬の飼料 の補給源が絶たれた。これにより明治 18 年には, 村費の溚納者が続出し，その滞納額は 5, 600 円 に達し，また地租改正の実施により，測量費・図 面作成などの諸経费が民間に分担され，入谷地区 の農家では，1,530 円の共同負債を負った。

\section{2 稲取村における震村計画}

(1) 天草（てんぐさ）の改良方法

田村又吉は稲取村の農業・漁業経営の不振を改 善するために地場産業の開発振興を強力に進めた。 それが天草の乾燥改良方法であった。稲取村の特 産物であった天草は, 明治 5 年, 沼津藩庁に納金 して採取権の払い下げを受け，村の共有とするこ とができた。明治 36 年の漁業法発布により惯行 による専用漁業として出願し, 明治 41 年, 漁業 原簿に登録され権利が確定した。 
天草の乾燥改良方法については，これまでの天 草の乾媿法は，浜辺や道路の両側などで乾かして いたが，砂などが混入したり甚だ品留が粗悪であ り利益も少額であった。田村又吉は品質改良を研 究した結果, 探取された天草を淡水で洗い，塩分， 砂を取り除き竹の篻を海岸に作り，そこに天草を 掛け乾燥させた。それにより品質の均一化，品兵 の向上につながり，利益が著しく増大した。その 採取労銀は，江木置によれば「天草ノ採取料八毎 年村会二於テ物価及天草相場ノ高低 7 察シ, 其穓 金习定ムルモノナル ハ一村ノ共有ナレバ，本村民タルモノ八，何人卜 踓モ之ヨ採取スルヨ得ルナリ。凡ソ一人一人ノ採 草料八其収襀高二依ル八無論ナルモ，男女概シテ 五拾銭以上三四円マデノ収益 貫上二関シテハ事務所 常雇若干名ヨシテ該事務ノ一切 長八委員長トナリテ之ヨ監督スルモノナリ“へ”」 とあり，また，片山潜によれば，「採取時期は， 毎年四月一日より，九月三十日迄とす。其間村民 は皆自由に採取に従事する事を得るなり。（中 略）近年の買上価格は，二百三十五多を一銭と定 む。各人の巧拙に依ると碓ども，女子にても一日 一国五十銭位を得ると決して困難にあらず，一期 節間に婦人にして百五十六円を得る者往々之れあ りと云ぶ121」とある。天草の採取期間は4 月か ら9月であり，村民は自由に採取でき，村役場ま たは村長がすべてを取り仕切るシステムができあ がっていた。また婦女子にも，現金収入の獾得の 機会が広がり，村民には兼業の機会が増え，非常 に大切な地場産業となった。村民が採取して集め られた天草は，村役場に持ち込まれ，同氏が考案 した乾燥方法により干され，乾いたものを主に大 阪商人に売り渡した。ほほ毎年の採取その他の諸 費用は 50 \%以下であり，その他の残金は村の純 益となった。また内務省の許可を得て，この純益 金の一部は村立小学校の基本金として積み立てら れた。これにより村民は学校教育に関してその费 用を負担することなく子弟の教育を受けられた。

稲取村が「天賦の富源」をもち、この天草の採 取権を村の共有とし，それを役立たせるために改 良した同氏の功績は大きなものがあるといえる。
また，男女を問わず現金収入獲得の機会をつくっ た事は，農村振興を行っていく上でも重要なこと であった。これ以後の町村自治財政，農村振興に 资するころが非常に大きい。小学校，役場，病 院, 道路, 水道, 植林事業などの施設経営はこれ を財源とした。

\section{(2) 植林および靴業}

植林については，村基本財産の造成として，副 次的な目的として防風林，魚付林となるように進 められた。明治 22 年に当時の村長・田村又吉が, 隣村より山林 15 町歩を瞵入し, 町有原野であっ た 35 町歩と併せて 50 町歩に松・杉・㭘の苗を 81 万本植林した。当初の計画では，2 百万本を植 林し百万本は間伐・枯損などと考え, 残りの百万 本が 1 年に 1 本 1 銭ずつ成長するとして 25 年後 に合計 2 万 5 千円となり，大きな基本財産となる と考えた。また，天城山の入会権竦失による農家 の下草刚，採草等の場を造る意味でも重要であっ た。同氏は植林事業は天地銀行への預金であり， 銀行人預金すれば利子が付くのと同じく植樹は天 地の恩恵で年々成長し価値が増加すると説いた。

農業の勧業に関して，前に述へた入谷地区の地 租改正費やその他の滞納金などの共同負债 1,530 円は当時の農家にとって巨額なものであった。ま た土地生産性が低く，天城山の入会権岥失などに より農家程営は困筑していた。村長となる以前の 明治 12 年, 田村又吉は, 入谷地区の共同負債返 済のため下記の方法を立てその救済を計った。(1) 鉫倹貯蓄奖励，(2)縄ない，炭俵編をなして月末に 役場に持参すること，(3)1 ケ月1日ずつ共同作業 で共有金を造ることが決められた。この方法を奏 行したことにより, 明治 15 年には負債を完納し， 2,000 円の剩余金を得るまでになった。この剩余 金の利子を勧業費として精耕会非13) という会をお こし，剩余金を蓄積して共有の山林原野 60 町歩 を買い入れ，一部には杉，㭘を植樹した。この会 が後に入谷地区を中心に組織される農家共同救膵 社の起源とされる。

(3)養董および副業の振興

次に養蚕業であるが，農家の副業として明治期 
の農村ではどこでも奖励されたものであるが, 明 治 19 年, 田村又吉が稻取村外 4 ヶ村勧業委員で あったこともあり，同地域の養虫業の不振を夏え， 桑苗園を設け無償で農家に分配する事を村会で決 め, 各戸に分配し採苗の方法を教えた。しかし, 当初から成功したわけではなく，明治 27 年頃か ら次第に普及するようになった。入谷地区 145 戸 をはじめ明治 37 年では 190 戸に達し, 桑畑 80 町， 1 户平均 143 円の収益をあげるようになった。こ れに関連し, 山林開発を計り, 前の入谷地区の共 同組織を中心に明治 28 年までに 70 町 2 反の開䊗 地を作り上げた。この開秋地では桑植林を中心に 間作として陸稲，甘藷等の栽培が奚励された。蔽 の出荷に際しては明治 32 年, 社団法人の認可を 得た「救護社」の前身が共同出荷組合方式をとり， 仲買商人を入れず売買した事により価格は安定し， 荃㔻家に入る収益は大きなものがあった。労力と 報酬の関係をよく考える事が肝要であるという考 えもつ同氏の発案からであった。

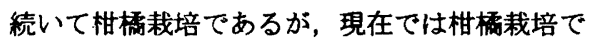
著名な産地となっている。田村又吉が戸長時代の 農政で, 「予備軍」として経営目標に設定し, 導 入を試みたが，柑㛢類のような永年性作物は栽培 後、数年間は収益が期待できないものであり, 明 治中期頃では，柑檽類の特産物化は困難なもので あった。本格的な導入は, 明治 37 年頃であり, 大正年間に入ってから特産物となっていった。

\section{(4) 納税方法}

村財政の要である徵税については，納税組合を 設け，漁業・商人・農民に分け甲・乙・丙の三形 態の組合を設け，各組に「代納者」という徽税請 負人をたて代納者に組合と役場を仲介させた。こ の方法により税の徵収は一戸の滞納者もでなくな った。江木翼によれば，「本村二於ケル諸税徽収 法トシテ八, 各戸凡ソーヶ年度ノ負㩈納税類 7 役 場二於テ調查シ, 之ヨ村民二示シテ, 各自ノ納税 負撚額二従七，日掛ケノ方法ヨ以テ，十五戸乃至 二十戸二集金ノ預山世話人ヨ設置シ, 毎日毎戸順 番工, 組内ノ各戸ヨリ或銭若シク八参銭ト云フガ 如クニ之ヨ集メ，其集金明預り世話人 7 渡シ， 世話人八又之ヨ毎月十ノ日ヨ以テ役場ニ預クルモ
ノトス 年14)」と述べられ，この徽税方法の結果, 稲取村の税金は完秋され，村民は税金の皘み立て により，納期に滞納者のでる心配がなくなった。

\section{IV 田村又吉の農村振興思想}

前節では, 稲取村の農村振興に関して重要な事 柄を扱った。本節では，老農・田村又吉に焦点を あて論述していく。

田村又吉は, 稲取村入谷に篤宸家, 田村栄截 (屋号大門家) の長男として, 1841 (天保 13) 年 1 月 5 日に生まれた。15 歳まで寺子屋教育を 受けた。当時の農家の教育としては進歩的な境遇 であり，これが後の農業思想，人生観に大きな影 整を与えている。30 歳まで家業である農業に従 事し，農業経営の体験から農村社会の将来を展望 するようになった。二宮尊徳の報徳思想を持論と し, 各種集会で発言していた。明治 20 年に浦役甘 15) となり，稲取村戸長を兼務し，明治 22 年, 稲 取村長となった。稲取村の町村自治, 農村振興の 結果，全国の模籁村として推桨されたことにより， その貢献が大きい田村又吉には, 明治 37 年 7 月, 藍綬褒章が授けられ，また明治 38 年 5 月，大日 本農会総裁大喠位貞受親王殿下より紅白綏有功章 を贈られている。晚年期には，各地 2 府 19 县か らの要請で自治汻業の経験䚿を行っている。最後 に群馬県富岡町の招きにより出発し，天城山中に て発病し大正元年11月 14 日，71 歳で逝去した。

明治 24 年 12 月, 田村又吉は定例村議会で稲取 小学校建設予算を提案し可決されたが, 農政面で 同氏の報德主義思想があげられ，村議員の一部か ら「地主的支配を根底とした報徳思想の強要は一 方的で片寄りすぎだ」との批判を受け, 明治 25 年 3 月，任期を 1 年残し村長熾を辞任した。辞任 してからの同氏は, 妻に羽織袷を焼き捨てさせ, 粗末な野良着をまとい一介の農夫として農民レヴ エルでの村作りを心がけ，村長職の経験から直接 的に一般農民との共鳴ができなかったことを学び， 一農民として農村改良に取り組みだした。

これ以後の活動乞しては, 入谷部落を中心に結

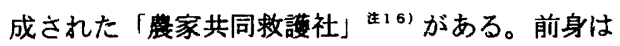
前述した入谷地区の精耕会であり, 明治 26 年に 
は入谷部落に戸主会, 母会, 背年修身会, 処女会, 者老会などの風俗矯正組織を結成し，戸主会で决 議したことを各家庭に知らせ徽底させる組織作り

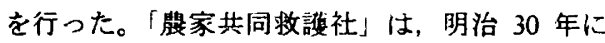
「共同救讙社」と称し, 明治 32 年, 社団法人と なり「救護社」となっている。明治 28 年, 田村 又吉が報德教育者，庵原郡庵原村の片平信明を訪 問し，報德社設立の教示を得て帰村した結果，創 設された。本会は，農民の借財一掃を念願し，低 利金融の相互扶助機関として結成され，農業の铼 業なども行い, 60 年を 1 期として運営された。 村落共同体を基碪に「勤労」、「至誠」、「貯蓄」と 自己に対してきびしく，他人に対しては「公益」，

「豊かな村」を摽題とした報徳主義的教育を行っ た。報徳金という規定を設け，救護社の組合員は 農産物，美虫業の収入の 1 割以上を毎年榬み立て ることが義務づけられ、これを元金とし貧困農家 に対し産業金として貸し付けられた。これによ り組合員は養蛋業，植林に着手し，大きな発展を 遵げている。また，善種金と称し，組合員が毎月 定期集会に各自が節約し，夜業をして得た金銭物 品を持ち奇り善種金として差し出した。この用途 は，陸海軍部への献金，赤十字社への寄付，優良 農民の表彰, 神社仏閣への奇付, 䍜災者救済など に使われた。この報德金の利息，残金は土地の購 入や公共事業，特に国債に支出され地域および国 家に貢献するところが大きかった。

救護社の総会は，田村又吉を中心として入谷部 落で組織された戸主会であり，毎月15日に行われ た。その他に入谷耆老会，入谷青年報徳夜学校， 入谷母会，入谷処女会などを設け風俗矯正，青年 教育を施した。総会の主な事項は, (1)報徳の仕方 の研究を主として殖物富産の法を起こすべき事。 (2)勤侩を行い筑民を救済し共同救護をなす方法等 の事。(3)家庭教育を進歩せしむる等の事。(4)風俗 を淳良ならしめ徳義を厚くする事。(5)業務報告, 財産報告, 決算報告, 善種金奇付者氏名報告等の 事であり，部落全体の決定事項，殖産研究の交換 検討を行った。また，田村又吉の各地視察談など を行い, 経験談の交換を行った。田村又吉は二宮 尊徳の精神を满法し，農業者の根本精神を養い， その精神の上に産業の発展を計ろうとした。
老農・田村又吉の思想は，戸長，村長の時代以 前から私心を抑え，稲取村の振興のために，報徳 主義に基づく，全体一の奉仕者として活動を行っ ていく心棈えが伺える。その結果，公職を辞した 後も一農民として部落をもつて組織した報徳主義 結社である共同救荽社の活動に及んでいった。こ の田村又吉扎よひ稲取村の町村白治は，地方改良 運動のシンボル的存在である模範村として各地か らの視察，同氏の各地での講演などにより稻取村 は脚光を浴びることとなった。内務官僚が推進し た報徳思想の再評価もその要因であった。

\section{$\mathrm{V}$ 模範村の形成と農村計画的な意義}

模範村の設定は，明治中期の前田正名在中心と した全国擘事会による活動で行われた。地方産業 及び各町村農会の振興を目的としたこの連動では 優良町村およびその活動を表彰，喧伝する事によ り, 各地域の農業者（この場合，在村手作り地主, 篤農家など）の活発な活動，取り組みを鼓舞し， 促進のために模籁村の設定を行った。明治後期か ら大正期に入り，村落共同体の変容が著しく，ま た，わが国の帝国主義化，国際政治経済体制に組 み込まれたことも要因となり，内務省が展開した 地方改良運動は，疲弊する町村に主体的に「自立 振興」を促し，村落の振興に役立つ報徳主義を利 用し, 町村自治の発展, 勤俟貯蓄, 風俗矯正など を呼びかけ，国民教化，村民精神の改革に取り組 んだ。行政町村が主体的役割を担い町村民の意識 的統一を図り，町村一体の振興を行うことを求め た。このときに前史で行われた優良事例である模 範村を喧伝し, その町村の活動を模範とし, 各町 村に活動を行うように促した。稻取村に関して特 筆すべきは，寒村状態においてなお炎厄を受けた 状態から振興したことであり，稻取村が脚光を浴 びる要因でもあった。稲取村の振興及び田村又吉 の活動が，明治中期であり地方自治制度の成立期 または初期にあたる。天草の改良法が早期に実を 結んだ結果と村長であった田村又吉の活動もあり， 「明治の三大模範村」となることがー゙きたと考え られる。また，地方改良運動の中心的イデオロギ 一である報徳主義, それ実地で行って町村自治 
組織に早期に組み込んだ事もその要因の一つであ るといえる。

現代の地域振興でも，指導者の资質，行政機関 の果たす役割は重要なことであり，また，地域の 独自性，個性を活かした地域振興が求められてい るといえるであろう。稲取村の振興策，報德思想 は，現代と地域を取り巻く状況も異なり，また振 興方法も模做はできないが，稲取村の振興からは， 「地域资源の再評価」，「地域资源活用一の努力と その実践」「加工と販売の総合化」，「地域行政主 導の計画的振興」，また「地域住民の協力，協 調」など，地域の独自性，主体性を考える際の参 考となる点は大いにあるといえる。

[注)

1) 近代日本の地域振興の変要については, 田中学

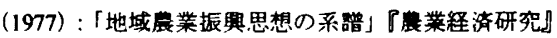
第 49 巻, 第 2 号 pp51．および守友裕一（1991）: 『内発的発展の道』，農山漁村文化势会. pp29 器。

2 ) 静岡県賀茂郡稲取村，千葉県山武郡源村，宮城紧名 取郡生出村の三村である。明治 36 年に発足した「自 治势会」により明治 38 年 2 月に表彰された。

3) 考支献 1) pp128 参照。

4) 明治 42 年から大正 12 年頃まで継䋨されていた。主 な誨演者は内務省官僚など。中央の活娌に影整され， 各地方自治体主催の講習会も開催された。

5 ）周知のように報徳思想は二宮草徳が道徳と程济を併 せて説いた教えであり，報德仕法とは薯徳が創始し た生活様式で，困第を制い安全な生活を営ませる方 法のことである。別名では，報徳教とも文われる。

6）中央報徳会は明治 37 年に報徳主義に興味を持つ有志 の集会に端発し，天皇制官僚，実業家，学者など が組織し，明治 39 年から『斯民』を発行し報徳主義 の再評価, 研究を行った。中央報徳会の橝成員は地 方改良通的の推進主体と重䙨し，その政策思想が反 映されている。
7 ) 田村又吉に関する文辣には老辳という語句が多く使 われている，至考文献 3）参照。それらを踏裝して 老鹿とする。また，耘村内部階層については明治初 期から费村振興が成功したことにより地主小作成係 大きなものは見られない。

8）稲取村および田村又吉に関する主要文献及び資料は，

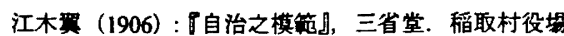
（1956）:『田村又吉翁』. 艮沢則彦（1905）：『模筑自 治村』，新公論社. 内務省地方局（1903）:『模筑的町 村治』. 富田耧治（1907）:『稲取美談』. 市川愎吉 （1907）:『模筑自治村稲取村の治䍃』，成美商会なと。 9）产支献 2) 明治 35 年全村調查統計加5。

10）考支献 4) pp38 から pp40参照。

11）参考文献 3) pp81 参照。

12 ) 考文献 2) pp2 照。

13 ) 裳事の研究が目的で，毎月 1 回部落民が会合し, 田村又吉を中心に諸種展事の実倹や意見を交䒨した。

14）考支文献 3) pp33 照。

15 ）浦役とは，漁村で浜や漁業を管裳する役㧴であり， 戸長とは, 明治初期, 町村制施行以前の町村の行政 事務を司る碚である。

16）参考文辣 3）には，一貫して鹿家共同救讙社とな っており，名称変更は関係なく内容は同じである。

〔考・引用文献〕

1) 宮地正人 (1987)：「国際政治下の近代日本』，山川出 版社.

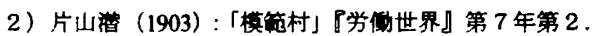

3）江木買（1906）:『自治之樭籁』，三省堂.

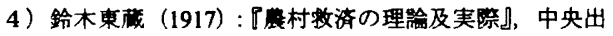
版社.

5) 内政史研究会編（1984）:『斯民』，不二出版.

6）大滑会編（1980）:『内務省史』，原费房.

7) 守友裕一（1991）:『内発的発展の道』，鹿文協.

8 ）磯辺俊彦 $(2000)$ : 『共の思想』, 日本経済評論社.

The purpose of this study is to review the procedures and progress of rural promotion by the Ministry of Home Affairs and Inatori village of an advanced village during modem Japanese capitalism.

The report summarize ;

1) the analysis of rural planning and rural self-government of the advanced village (Inatori village).

2 ) the investigation of the advanced village's roles in the rural promotion. 